\title{
CARBONACEOUS DEPOSITS (CARBONIFEROUS) AND OIL AND GAS POTENTIAL PROSPECTS OF THE MAGNITOGORSK TROUGH (SOUTH URALS, RUSSIA)
}

\author{
A.M. Tyurin ${ }^{\mathrm{a}, \mathrm{b}}$, A.V. Kolomoets ${ }^{\mathrm{a}, \mathrm{b}}$, A.V. Snachev $^{\mathrm{c}}$, I.V. Smoleva $^{\mathrm{d}}$, \\ P.V. Pankrat'ev ${ }^{\text {b }}$ \\ ${ }^{a}$ Volga-Urals Research and Design Institute for Oil and Gas, Orenburg, 460000 Russia \\ ${ }^{\mathrm{b}}$ Orenburg State University, Orenburg, 460018 Russia \\ ${ }^{\mathrm{c}}$ Institute of Geology, Ufa Federal Research Center, Russian Academy of Sciences, \\ Ufa, 450077 Russia \\ ${ }^{\mathrm{d}}$ Institute of Geology named after Academician N.P. Yushkin, Komi Science Center, \\ Ural Branch, Russian Academy of Sciences, Syktyvkar, 167982 Russia
}

\begin{abstract}
The oil and gas potential prospects of the Magnitogorsk trough in the South Urals were studied and substantiated using the data of the geological survey and deep-well drilling. Based on the results of the seismic, gravity, and magnetic explorations, a large unit was detected in the Lower-Middle Carboniferous carbonates of the Kizil zone. The oil and gas blowouts were registered in the drill holes. To further explore the oil and gas potential of the region, the features of black shales were analyzed. It was shown that the Kumak ore field shales are promising sources of oil, depression analogues of the Lower-Middle Carboniferous shelf carbonates. Therefore, we recommend that the black shales of the South Urals should be further studied for their oil and gas potential. The major tasks for future research are as follows: localization of facies of the carbonate sedimentation basin within the Magnitogorsk trough and the East Urals uplift, as well as development of its geological and geophysical model; assessment of the oil and gas potential prospects of the region with the help of the developed model; substantiation of regional CMP seismic surveys.
\end{abstract}

Keywords: carbonaceous shales, organic carbon, carbon isotope composition, sedimentation basin, oil and gas potential, South Urals, Magnitogorsk trough, East Urals uplift

\section{Introduction}

The territory of the Bashkortostan Republic is occupied by the Magnitogorsk megazone (megasynform) with its several structural-facial zones. The Magnitogorsk trough runs along the Orenburg segment of the Urals fold system. It is bordered from the east and west by the outcrops of heterochronous metamorphic and volcanogenic rocks, which determines how the oil and gas potential of the poorly explored areas is assessed. In Kazakhstan, the Magnitogorsk trough corresponds to the Bakaiskaya syncline. The southern closure of the trough is the Berchgurskaya syncline.

The Magnitogorsk trough of the South Urals has been studied by means of geological surveys, gravity and magnetic explorations, drilling, and driftage. Most studies were 
performed on the following topic: "Geological mapping and exploration of solid mineral fields". In 1991-1992, three CMP regional seismic profiles (total length $142.9 \mathrm{~km}$ ) were acquired in the Orenburg segment for oil and gas exploration. Their depth charts appear on paper only. The features of fault and lithological traps were distinguished. An anticlinal turn in the reflection events was found in one of the profiles. To assess the oil and gas potential prospects of the section explored by the seismic survey, the 1 Ashchebutakskaya parametric well (target depth $1600 \mathrm{~m}$, true depth $1261.2 \mathrm{~m}$ ) was drilled. In the interval from 0 to $303.5 \mathrm{~m}$, heavy and sticky gray clays of the Jurassic age with the occasional sand interbeds were penetrated, while the lower area, up to the face end, contained light-gray and gray limestones (massive, thickbedded, organogenic-detrital) bearing the Visean fauna.

Previously, the data on the Magnitogorsk trough were interpreted to assess its prospects for oil and gas exploration. As a result, we developed a model of the carbonate sedimentation that took place in the region during the Lower-Middle Carboniferous [1]. Its marginal-marine zones were a reservoir for terrigenous and carbonateterrigenous deposits. Farther from the margin, there was a zone of predominantly carbonate sedimentation (shelf), where the thickness of limestones reached 1000-1300 m. Behind it, a side scrap of the carbonate massif is predicted. Thin analogues of the shelf limestones accumulated in a relatively deep-water uncompensated depression. Their bottom part (black shales) was studied in the Kumak ore field. In the uncompensated depression, isolated carbonate buildups developed.

Large morphological traps of hydrocarbons confined to the side scrap and isolated carbonate buildups of the Lower-Middle Carboniferous may be discovered in the Orenburg segment of the Magnitogorsk trough. Structural traps are predicted in carbonates of the shelf area. They are overlaid by sticky clays of the Jurassic strata (cap rock). In the marginal-marine zone (terrigenous and carbonate-terrigenous deposits), structurallithological traps (sandstone beds overlaid by argillites) are predicted. The Orenburg segment of the Magnitogorsk trough is a promising field for oil and gas extraction.

This paper further analyzes the oil and gas potential prospects of the Magnitogorsk trough based on the study of its carbonaceous shales as oil source rocks and shelf carbonates analogues. The priority problems for further studies of the region are outlined.

\section{Black Shales of the Magnitogorsk Trough and Adjacent Areas}

The marginal eastern part of the Magnitogorsk trough hosts the Amur stratiform zinc deposit intruding the western limb of a meridian-elongated brachyanticline fold (Fig. 1). The following two sequences can be identified in the deposit section (from the bottom upwards): ore-bearing terrigenous-shale-carbonate (flysh, $\mathrm{D}_{2-3}$ ) and volcanogenic $\left(\mathrm{C}_{1}\right)$. The terrigenous-shale-carbonate deposits are represented by rhythmically interbedding aleurolites, limestones, as well as clayey, carbonaceous-clayey, siliceous-clayey, limestone-clayey, biotite, and quartz-feldspar-biotite shales. The total width of the penetrated deposits is about $850 \mathrm{~m}$. Similar to the units located northwards, the studied sequence is suggested to be of the Middle-Upper Devonian age [2].

In the east, the Magnitogorsk trough is conjugated with the East Urals uplift. Its southern part comprises the Bredinskaya Formation $\left(\mathrm{C}_{1} \mathrm{bd}\right)$, which composes the elongated submeridional blocks of the rift-driven Anikhov graben. Its width is about 350$700 \mathrm{~m}$. The section of the sequence is dominated by aleurolites, carbonaceous-clayey 


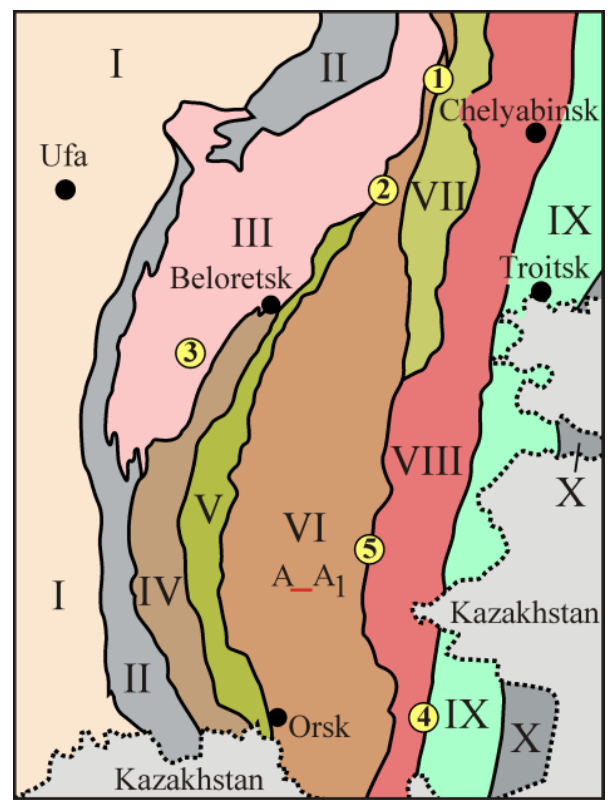

Fig. 1. Geological scheme of the South Urals and objects discussed in the paper, according to [3-5], simplified by the authors. Designations: Structural-formational zones: I - East European Craton; II - Pre-Urals foreland basin; III - Bashkirian anticlinorium; IV - Zilair anticlinorium; V - Uraltau anticlinorium; VI - Magnitogorsk megazone; VII - VerkhoturyeNovoorenburg zone; VIII - Alapaevsk-Adamovka zone; IX - Krasnogvardeiskoe-Svetlyi zone; X - Uray-Denisovskaya zone. Gold deposits and occurrences in black shales: 1 - Chernoe Ozero; 2 - Siratur; 3 - Ulu-Yelga; 4 - Kumak; 5 - Amur. A-A - Uralian profile

shales, and sandstones. Rare limestone and coal interbeds are present. The finds of foraminifers in the limestone interbeds, microfaunal remains, spores (those of ferns, calamites, and other plants) allowed dating the deposits $\left(\mathrm{C}_{1} \mathrm{t}_{2}-\mathrm{v}_{1}\right)$ [6]. The carbonaceousclayey deposits of the Bredinskaya Formation, within the limits of the Kumak ore field, are called "black shales" (because of their dark gray to black color). Their petrochemical features, chemical and mineralogical composition, texture, and metamorphic transformations were studied. The typification was carried out; the paleogeographic and physicochemical conditions of sedimentation were reconstructed $[7,8]$. Based on the lithochemical classification, they correspond to siallites and siferlites [7, 9].

Black shales of the Kumak ore field are rich in gold, which is fine-grained, associated with sulfides (pyrite, arsenopyrite), and high-carat (919-1000). The maximum registered gold grade is $17.7 \mathrm{~g} / \mathrm{t}$ [10]. Commercial gold and tungsten contents have been found in the shales of the Amur deposit [2].

\section{Black Shales as Oil Source Rocks and Analogues of Shelf Carbonates}

The $\mathrm{C}_{\text {org }}$ content in the samples from the Kumak deposit amounts to $4.0 \ldots 11.1 \%$ (Table 1), $6.4 \pm 2.4 \%$ on average. Sample KM037s of the black shales was pyrolyzed by the Rock-Eval method using a Lithotherm-1000 mass spectrometry analyzer (O.K. Navrotskii, Lower Volga Research Institute of Geology and Geophysics, Saratov). The sample had a weight of $100 \mathrm{mg}$. The TOC (total organic carbon) and $\mathrm{S}_{2}$ (hydrocarbons from cracking of kerogen and asphaltic-resinous components) values 
Table 1. $\mathrm{C}_{\text {org }}$ content and $\delta^{13} \mathrm{C}_{\text {org }}$ in the black shales of the Kumak and Amur deposits

\begin{tabular}{|c|c|c|c|c|c|}
\hline Sample no. & $\mathrm{C}_{\text {ogr }}, \%$ & $\delta^{13} \mathrm{C}_{\text {org }}, \%$ Sample no. & $\mathrm{C}_{\text {org }}, \%$ & $\delta^{13} \mathrm{C}_{\text {org }}, \%$ o \\
\hline KM026s & 5.1 & -19.58 & AM-38/139 & 1.8 & -21.6 \\
\hline KM025s & 7.3 & -19.16 & AM-40-178 & 4.5 & -16.9 \\
\hline KM024g & 6.0 & -22.80 & AM-65/228 & 3.4 & -17.7 \\
\hline KM023g & 9.2 & -21.73 & AM-78/401 & 2.1 & -14.4 \\
\hline KM015g & 5.1 & -19.84 & AM-39/172 & 5.3 & -16.6 \\
\hline KM014s & 3.8 & -19.93 & AM-40-161 & 5.8 & -19.2 \\
\hline KM009s & 4.8 & -20.39 & AM-10/318 & 6.0 & -15.0 \\
\hline KM005s & 4.0 & -22.76 & AM-11/486 & 3.1 & -13.5 \\
\hline KM031s & 7.4 & -19.07 & AM-81/289 & 2.7 & -17.9 \\
\hline KM037s & 11.1 & -20.11 & AM-19-203 & 1.0 & -19.8 \\
\hline
\end{tabular}

Note: KM - Kumak deposit; AM - Amur deposit. All samples were analyzed in the "Geonauka" Center for Collective Use of the Institute of Geology of the Komi Science Center, Ural Branch, Russian Academy of Sciences.

were $0.62 \%$ and $0.27 \mathrm{mg} / \mathrm{g}$, respectively. $T_{\max }\left({ }^{\circ} \mathrm{C}\right)$ was $606{ }^{\circ} \mathrm{C}$. Functionally, $\mathrm{S}_{2}$ shows the residual oil potential of the rock, i.e., it indicates the part of it that has not yet turned into oil or gas in the natural evolution of the organic matter (OM). The studied sample had an extremely low (but not zero) oil potential, thereby implying the ongoing catagenesis (metamorphism) of the original OM of its black shales into graphite. $\mathrm{S}_{2}$ was related to $\mathrm{C}_{\text {org }}$ by a factor of 0.83 . Sample KM037s contained $11.1 \%$ of $\mathrm{C}_{\text {org }}$. About $2 \%$ of TOC was OM carbon, which corresponds to $\mathrm{S}_{2}$. Graphite accounted for 98\% of TOC. The oil potential of the sample was exhausted to $98 \%$.

In [11], the Suranskaya Formation $\left(\mathrm{RF}_{1}\right)$ shales of the Bashkirian megaanticlinorium were studied: $\mathrm{C}_{\text {org }}$ ranged from $0.6 \%$ to $2.2 \%$. The $\mathrm{OM}$ had a complex phase composition: asphaltites, kerite, and oxykerite. Cryptocrystalline graphite was traced. Metamorphism occurred within the green shale facies.

Therefore, the South Urals host black-shale horizons undergoing metamorphism characterized by the $\mathrm{OM}$ conversion into graphite.

In the marine limestones, $\delta^{13} \mathrm{C}$ is close to zero. In the East Urals, the $\delta^{13} \mathrm{C}$ of limestones is $1 \ldots 2 \%$ in the Devonian (Famennian) stage, $2.0 \ldots 2.5 \%$ to $6.9 \%$ in the Carboniferous (Tournaisian) stage [12]. $\delta^{13} \mathrm{C}$ of carbonates from the shales of the $\mathrm{Su}$ ranskaya Formation is $-4.3 \ldots-1.1 \%$ [11].

The OM carbon isotope composition $\left(\delta^{13} \mathrm{C}_{\text {org }}\right)$ of the bottom sediments is $-21.1 \%$ in the Gulf of Mexico, $-23.5 \%$ in the Florida Bay, and $-23.3 \%$ in the Santa Barbara Bay [13]. $\delta^{13} \mathrm{C}_{\text {org }}$ of the bottom sediments is $-25.0 \%$ in the White Sea, $-25.1 \%$ in the Kara Sea, $-23.6 \%$ in the Barents Sea, $-22.7 \%$ in the East Siberian Sea, and $22.3 \%$ in the Chukchi Sea [14].

The above values show the average $\delta^{13} \mathrm{C}_{\text {org }}$ in the bottom sediments. In the bottom sediments of the Laptev Sea and the East Siberian Sea, the values of this parameter are in the range of $-27.40 \ldots-20.85 \%$ [15]. $\delta^{13} \mathrm{C}_{\text {org }}$ of bottom sediments is determined by the ratio of marine carbon from phytoplankton (sapropel) and river carbon (humus). Near the coastal areas of the seas, the parameter equals $-27 \ldots-24 \%$, while farther from the coast, in upper part of the continental slope, it decreases to $23 \ldots-21 \%$. In the $\mathrm{Ob}$ River estuary, the $\delta^{13} \mathrm{C}_{\text {org }}$ values vary in the range of $-37 \ldots-$ $28 \%$ [14]. In May, the $\delta^{13} \mathrm{C}_{\text {org }}$ values in the Dnieper River mouth and in the northeastern part of the Black Sea are $-29.0 \ldots-28.5 \%$ and $-26.1 \ldots-25.0 \%$, respectively 
[16]. $\delta^{13} \mathrm{C}_{\text {org }}$ of marine plankton is $-22 \ldots-20 \%$ [14]. For the forest soils of the Moscow and Bryansk Regions, this parameter equals 32.69...24.38\%o [17].

The catagenetic transformation of OM in the oil source rocks is accompanied by oil and natural gas migration. $\delta^{13} \mathrm{C}_{\text {org }}$ of oil is almost equivalent to the $\mathrm{OM}$ of the oil source rock. For most oils, $\delta^{13} \mathrm{C}_{\text {org }}$ varies from $-34 \%$ to $-18 \%$ and depends on the original OM type (sapropel or humus). However, natural gas generation causes carbon isotope fractionation. For thermocatalytic gases of marine sediments, $\delta^{13} \mathrm{C}_{\mathrm{org}}$ is from $-50 \%$ (low maturity degree of oil source rocks) to $-30 \%$ (overmature rocks) [18]. $\delta^{13} \mathrm{C}$ of methane in 12 largest deposits located within the northern part of Western Siberia (Cenomanian) is from $-56.5 \%$ to $-42.5 \%$ [19].

Black shales is the final stage of lithogenesis of bottom sediments rich in OM. Graphite is the result of catagenesis (metamorphism) of the OM in black shales. Yet, $\delta^{13} \mathrm{C}_{\text {org }}$ of graphite will differ from that of the original OM because of carbon isotope fractionation during the natural gas generation. Quantitative parameters of this process should be a subject of future research endeavors. For now, we are left with a glancing understanding that graphite and the original OM show no significant differences in $\delta^{13} \mathrm{C}_{\text {org }}$. Under this assumption, it seems possible to identify the OM composition of black shales based on their $\delta^{13} \mathrm{C}_{\text {org }}$ values (predominantly sapropel, predominantly humus, or mixed), as well as to specify the conditions that lead to the accumulation of their source deposits (river fan, marginal-marine, offshore areas of the sea basin).

In monograph [13], evidence is provided that the intensive thermometamorphism had no influence on the $\delta^{13} \mathrm{C}_{\text {org }}$ value of aluminosilicate shales (Sweden). The samples taken from the zone of contact with diabase dikes and the samples of unmetamorphosed shales had similar $\delta^{13} \mathrm{C}_{\text {org }}$ values $(-29.0 \ldots-27.2 \%$ ).

The average $\delta^{13} \mathrm{C}_{\text {org }}$ value of shales in the Suranskaya Formation (7 samples) is $-19.0 \pm 2.0 \%$ [11], which is slightly lower than the minimum value of this parameter in marine plankton $(-20 \%)$, but corresponds to that of oil $(-18 \%)$. According to the authors, this is likely to result from the impact produced by the magmatic melt invading the sedimentary deposits of the sequence. We attribute the somewhat overestimated $\delta^{13} \mathrm{C}_{\text {org }}$ value of the shales to the effect caused by the fractionation of carbon isotopes during the OM catagenesis. In this case, it indicates the sapropel origin of the OM.

In [11], $\delta^{13} \mathrm{C}_{\text {org }}$ of the black-shale deposits $\left(\mathrm{RF}_{2}\right)$ of the Ulu-Yelga-Kudashman zone of the Bashkirian megaanticlinorium was studied. The obtained $\delta^{13} \mathrm{C}_{\text {org }}$ values were $-29.1 \ldots-24.3 \%$ (11 samples) and consistently increased with depth. We explain it by the sea basin regression. The sea margin approached the bottom deposits that turned out to be the source of black shales. The amount of terrestrial humus was growing, while the $\delta^{13} \mathrm{C}_{\text {org }}$ value decreased.

The $\delta^{13} \mathrm{C}_{\text {org }}$ values of the black-shale samples from the Amur deposit fall into two groups: those within the range of $-19.2 \ldots-21.6 \%$ that correspond to carbon accumulated in a shallow-water basin; the second group is characterized by the clearly increased $\delta^{13} \mathrm{C}_{\text {org }}$ values associated with the carbon-rich deposits of pyrite-pyrrhotite mineralization, which points to the reducing conditions of their accumulation and to the hydrogen sulfide contamination in the bottom part of the local paleodepression.

For the carbonaceous shales of the Polyakovskaya Formation $\left(\mathrm{O}_{1-2} \mathrm{pl}\right)$, which is located in the juncture of the Bashkirian megaanticlinorium and the northern closure 
of the Magnitogorsk megazone (Siratur ore field, Chernoe Ozero gold occurrence) (Fig. 1), the maximum $\mathrm{C}_{\text {org }}$ content is up to $4 \%$ (2\% on average, based on the data for 4 samples) and the $\delta^{13} \mathrm{C}_{\text {org }}$ (5 samples) is $-27.28 \ldots-24.84 \%$ [20, 21, 22]. These values are characteristic of the bottom sediments in the marginal-marine zone. Therefore, the authors of the paper are right in their conclusion about the conditions of shales formation.

In the samples of black shales from the Kumak ore field, the $\delta^{13} \mathrm{C}_{\text {org }}$ value is $-22.80 \ldots-19.07 \%$ (Table 1). It had no correlation with the $\mathrm{C}_{\text {org }}$ content. The average $\delta^{13} \mathrm{C}_{\text {org }}$ value $(-20.5 \pm 1.4 \%$ ) perfectly corresponds to that of marine plankton. Thus, the OM composition of the shales is sapropel and without any terrestrial humus impurities. Technically, the bottom sediments that constitute the shales accumulated in the offshore area of the sea basin. In the reality, this process took place in the sea area with clean water, i.e., where there is the side scrap of the carbonate massif enriched in bioherm limestones. This substantiates one of the major elements of the model of a carbonate sedimentation basin that existed in the region during the Lower-Middle Carboniferous [1]. Black shales are the depression analogues of shelf limestones.

\section{Oil and Gas Potential Prospects of the Kizil Zone of the Magnitogorsk Trough}

As has been already stated, the oil and gas potential of the black shales in the $\mathrm{Ku}$ mak ore field is extremely low, but not zero. The deep-well drilling data from the Kizil zone of the Magnitogorsk trough (Uralian profile, Fig. 1) show that the Low and Middle Carboniferous limestones occur at a depth from 0 to more than $5 \mathrm{~km}$ (Fig. 2) [23]. Their depression analogues, black shales with the OM undergoing active catagenesis, may rest at the same depth. It means that they are continuously generating oil and gas. The latter factor may be associated with the oil and gas blowouts registered in the three wells. In the core of well 5, heavy oil and crude oil sweats occurred from the pores and fractures of the deposits of the Kizil $\left(\mathrm{C}_{1} \mathrm{v}_{2}-\mathrm{s} \mathrm{kz}\right)$, Gusikhinskaya $\left(\mathrm{C}_{1} \mathrm{~V}_{2}-\mathrm{s}\right.$ gs), and Urtazymskaya $\left(\mathrm{C}_{2}\right.$ ur) Formations. In the core of well 1, oil-stained walls of the fractures were seen in the deposits of the Berezovskaya Formation $\left(C_{1} t_{2}-v_{1} b r_{1}\right)$. From well 4 , the smell of oil gas was felt.

In [24], the hydrogeological criteria of potential oil and gas occurrence in the deposits penetrated by the drill holes of the Uralian profile are considered. Three hydrochemical zones were singled out in the section. At depths below $100 \mathrm{~m}$, nitrogenoxygen fresh waters are replaced by salt waters. The latter are replaced by methane brines of the calcium chloride type $(\mathrm{Cl}-\mathrm{Na}-\mathrm{Ca}$, mineralization $36-320 \mathrm{~g} / \mathrm{L})$ at depths below 2000-3000 m. They are relic metamorphized. In other words, the brines of this zone are shielded from the overlying zones. This factor favors the development of oil pools deeper than 2000-3000 m. In their another work, these authors also suggested that the calcium chloride brines turn out to be the major type of waters for oil and gas deposits in the sedimentation basins of the Epikarelian (East European and Siberian) platforms [26]. 


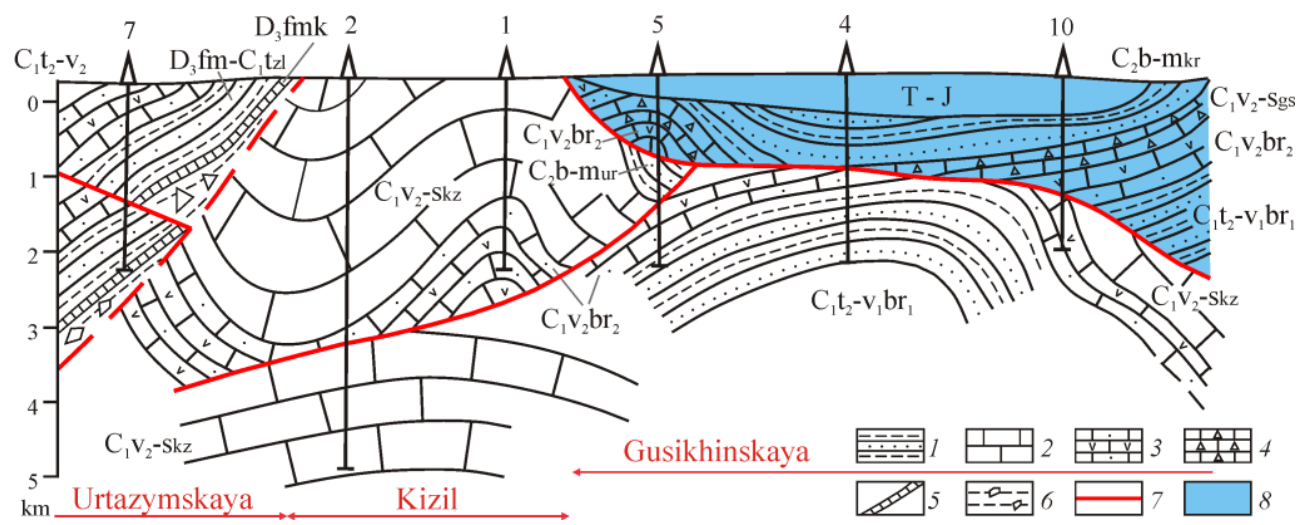

Fig. 2. Schematic geological section through the Kizil zone of the Magnitogorsk megazone based on the deep-well drilling data (Uralian profile) [23]. Structural-facial zones (red color) are mapped according to [25]: 1 - sandstones, aleurolites, argillites; 2 - limestones; 3 - tuff sandstones, tuffs; 4 - siliceous limestones; 5 - firestones; 6 - brecciated rocks; 7 - overlaps; 8 - Gusikhinskii allochthon. Upper Devonian: $\mathrm{D}_{3} \mathrm{f} \mathrm{mk}$ - Frasnian Stage, Mukasov Horizon; $\mathrm{D}_{3} \mathrm{fm}-\mathrm{C}_{1} \mathrm{t} \mathrm{zl}-$ Famennian Stage - Lower Carboniferous, Lower Tournaisian Substage, Zilair Formation. Lower Carboniferous: $\mathrm{C}_{1} \mathrm{t}_{2}-\mathrm{v}_{1} \mathrm{br}_{1}-$ Upper Tournaisian - Lower Visean Substages, bottom part of the Berezovskaya Formation; $\mathrm{C}_{1} \mathrm{v}_{2}-\mathrm{br}_{2}-$ Tula Horizon of the Upper Visean Substage, upper part of the Berezovskaya Formation; $\mathrm{C}_{1} \mathrm{~V}_{2}-\mathrm{S} \mathrm{kz}$ - Upper Visean Substage Serpukhovian Stage, Kizil ; $\mathrm{C}_{1} \mathrm{v}_{2}-\mathrm{s}$ gs - Upper Visean Substage - Serpukhovian Stage, Gusikhinskaya Formation. Middle Carboniferous: $\mathrm{C}_{2} \mathrm{~b}-\mathrm{m}$ ur - Bashkirian and Moscovian Stages, Urtazymskaya Formation; $\mathrm{C}_{2} \mathrm{~b}-\mathrm{m} \mathrm{kr}-$ Bashkirian and Moscovian Stages, Kardailovskaya Formation

In 2004, the detailed CMP seismic surveys were carried out in the area of the Uralian profile. Their results allowed mapping a large anticline, the buried Uralian anticline. It stretches meridionally and has a width similar to that of the Kizil zone. The presence of this structure has been confirmed by the data of the gravity and magnetic explorations (2005) [25]. It is located to the north of the Uralian profile and has been considered as an oil and gas prospective area.

\section{Conclusions}

The black shales of the South Urals are promising sources of oil. They deserve further studying as part of a large-scale research project focusing on the oil and gas potential prospects of the region.

Future studies of the oil and gas potential of the South Urals should be focused on the Program for Studying the Oil and Gas Potential of the Magnitogorsk Trough as a New Line of Research on Oil and Gas that includes:

- perceiving black shales as analogues of the Lower-Middle Carboniferous oil and gas prospective shelf carbonates;

- localization of facies of the carbonate sedimentation basin within the Magnitogorsk trough and the East Urals uplift, as well as development of its geological and geophysical model;

- assessment of the oil and gas potential of the region using the developed model;

- substantiation of CMP seismic surveys in the region. 
Acknowledgments. The study was funded by the Orenburgneft Company grant (2020-2021) and performed as part of the state assignment (Institute of Geology, UFRC RAS, Ufa, project no. 0246-2019-0078).

\section{References}

1. Politikina M.A., Tyurin A.M., Makarov S.E., Petrishchev V.P., Pankrat'yev P.V., Bagmanova S.V., Kolomoets A.V. Oil and gas potential prospects for the Orenburg segment of the Magnitogorsk trough. Neftegazov. Geol. Teor. Prakt., 2021, vol. 16, no. 1, pp. 1-19. doi: 10.17353/2070-5379/1_2021. (In Russian)

2. Snachev, M.V., Snachev, A.V., Puchkov V.N. New data on the structure of the Amur stratiform deposit (Southern Urals). Dokl. Earth Sci., 2015, vol. 463, no. 2, pp. 778-781. doi: 10.1134/S1028334X15080152.

3. Knyazev Yu.G., Knyazeva O.Yu., Snachev V.I., Zhdanov A.V., Karimov T.R., Aidarov E.M., Masagutov R.Kh., Arslanova E.R. State Geological Map of the Russian Federation. Scale 1:1 000000 (3rd generation). Ural series. Sheet N-40 (Ufa). Explanatory letter. St. Petersburg, VSEGEI, 2013. p. 512. (In Russian)

4. Lyadskii P.V., Kvasnyuk L.N., Zhdanov A.V., Chechulina O.V., Shmel'kov N.T., Belts G.M., Kurochkina E.S., Olenitsa T.V. State Geological Map of the Russian Federation. Scale 1:1 000 000. Ural series. Sheet M-40 (Orenburg). Explanatory letter. St. Petersburg, VSEGEI, 2013. 392 p. (In Russian)

5. Puzhakov B.A., Savel'ev V.P., Kuznetsov N.S., Shokh V.D., Shchul'kin E.P., Shchul'kina N.E., Zhdanov A.V., Dolgova O.Ya., Tarelkina E.A., Orlov M.V. State Geological Map of the Russian Federation. Scale 1:1000000. Ural series. Sheet N-41 (Chelyabinsk). Explanatory letter. St. Petersburg, VSEGEI, 2013. 415 p. (In Russian)

6. Lyadskii P.V., Chen-Len-Son B.I., Alekseeva G.A., Olenitsa T.V., Kvasnyuk L.N., Manuilov N.V. State Geological Map of the Russian Federation. Scale 1:200 000. South Ural series. Sheet M-41-I (Anikhovka). Explanatory letter. Moscow, VSEGEI, 2018. 100 p. (In Russian)

7. Kolomoets A.V., Snachev A.V. Geology and petrogeochemical features of the Kumak ore field carbonaceous shales. In: Chaplina T. (Ed.) Processes in GeoMedia. Vol. III. Springer, Cham, 2021, pp. 25-35. doi: 10.1007/978-3-030-69040-3_3.

8. Pankratev P.V., Kolomoets A.V., Panteleev V.S. Black shales of the Kumak ore district of the Orenburg region. Nedra Povolzh'ya Prikaspiya, 2018, no. 96, pp. 55-60. (In Russian)

9. Yudovich Ya.E., Ketris M.P. Geokhimiya chernykh slantsev [Geochemistry of Black Shales]. Moscow, Berlin, Direkt-Media, 2015. 272 p. doi: 10.23681/428042. (In Russian)

10. Snachev A.V., Kolomoets A.V., Rassomakhin M.A., Snachev V.I. Geology and gold content of carbonaceous shale in Baikal mineralization site, Southern Ural. Eurasian Min., 2021, no. 1, pp. 8-13. doi: 10.17580/em.2021.01.02.

11. Kovalev S.G., Kovalev S.S., Vysotsky S.I., Vysotsky I.V., Timofeeva E.A. Isotopic composition of carbon oxygen in terrigenous deposits of the Bashkirian meganticlinorium. Geol. Sb., 2017, no. 14, pp. 65-77. (In Russian)

12. Mizens G.A., Kuleshov V.N., Stepanova T.I., Kucheva N.A. Evidence for global Famennian and Tournaisian geologic events in the section of an isolated carbonate platform in the eastern Urals. Russ. Geol. Geophys., 2015, no. 56, no. 11, pp. 1531-1543. doi: 10.1016/j.rgg.2015.10.003.

13. Galimov E.M. Geokhimiya stabil'nykh izotopov ugleroda [Geochemistry of Stable Carbon Isotopes]. Moscow, Nedra, 1968. 226 p. (In Russian)

14. Lein A.Yu., Kravchishina M.D., Politova N.V., Savvichev A.S., Veslopolova E.F., Mitskevich I.N., Ul'yanova N.V., Shevchenko V.P., Ivanov M.V. Transformation of particulate 
organic matter at the water-bottom boundary in the Russian Arctic seas: Evidence from isotope and radioisotope data. Lithol. Miner. Resour., 2012, vol. 47, no. 2, pp. 99-128. doi: 10.1134/S0024490212020034.

15. Gershelis E.V. Geochemical features of the organic matter in bottom sediments of the Eastern Arctic seas. Cand. Geol.-Mineral. Sci. Diss. Tomsk, Nats. Issled. Tomsk. Politekh. Univ., 2018. 143 p. (In Russian)

16. Lein A.Yu., Ivanov M.V. Biogeokhimicheskii tsikl metana v okeane [Biogeochemical Cycle of Methane in the Ocean]. Moscow, Nauka, 2009. 576 p. (In Russian)

17. Kovaleva N.O., Kovalev I.V. Soil organic compounds as biomarkers of the paleoenvironment. In: Genezis, diagnostika i predotvrashchenie ekologicheskih krizisov [Genesis, Diagnostics, and Prevention of Ecological Crises]. Moscow, Maks Press, 2017, pp. 30-53. (In Russian)

18. Magomedov Sh.A., Mamaev O.A., Chupalaev Ch.M., Rasulov G.S. Measuring the degree of oil maturity by the isotopic composition of methane carbon. Vseros. konf. "Novye idei v geologii nefti i gaza”. Moskva, MGU, 25-26 maya 2017 g. [Proc. All-Russ. Conf. "New Ideas in Oil and Gas Geology". Moscow, Moscow State University, May 25-26, 2016]. Moscow, 2017, pp. 195-199. (In Russian)

19. Sobolev V.S., Polyakova L.L. Some features of the location and formation of the world's largest gas fields. Neftegazov. Geol. Teor. Prakt., 2009, vol. 4, no. 4, pp. 1-14. (In Russian)

20. Snachev A.V., Smoleva I.V. Carbon in the black shale deposits of the Siratur ore field (South Urals). Mater. Vseross. nauch.-prakt. konf. "Novye napravlenija rabot na neft' $i$ gaz, innovatsionnye tekhnologii razrabotki ikh mestorozhdenii, perspektivy dobychi netraditsionnogo uglevodorodnogo syr'ya" [Proc. All-Russ. Sci.-Pract. Conf. "New Fields of Research on Oil and Gas, Advanced Technologies of Their Exploration, Prospects for Extraction of Non-Conventional Hydrocarbon Fuels"]. Orenburg, 2019, pp. 121-124. (In Russian)

21. Snachev A.V., Latypov F.F., Snachev V.I., Rassomakhin M.A., Koshchug D.G., Vyatkin S.V. The Siratur gold deposit in carbonaceous rocks of an ophiolite association, South Urals. Moscow Univ. Geol. Bull., 2020, vol. 75, no. 6, pp. 609-615. doi: $10.3103 / \mathrm{S} 0145875220060113$.

22. Snachyov A.V., Kuznetsov N.S., Snachyov V.I. The Chernoe Ozero gold occurrence in carbonaceous deposits of the ophiolite association: The first object of such a type in the southern Urals. Dokl. Earth Sci., 2011, vol. 439, pt. 1, pp. 906-908. doi: 10.1134/S1028334X11060249.

23. Kazantseva T.T., Valiullin R.A. To the problem of oil and gas potential of the Magnitogorskskaya synform. Neftegazov. Delo, 2021, vol. 19, no. 5, pp. 6-19. doi: 10.17122/ngdelo-2021-5-6-19. (In Russian)

24. Popov V.G., Abdrakhmanov R.F. Hydrogeological prerequisites for oil-bearing capacity of the Kizil zone of the South Urals. Vestn. IG Komi NTs UrO RAN, 2017, no. 1, pp. 3-7. (In Russian)

25. Puchkov V.N., Kazantseva T.T. The large buried anticline in the Kizil zone of the Southern Urals. Dokl. Earth Sci., 2009, vol. 429, no. 1, pp. 1430-1434. doi: 10.1134/S1028334X09090049.

26. Abdrakhmanov R.F., Popov V.G. Deep-seated gas-liquid fluids of the Urals: Geochemistry, formation, genesis. Geol. Sb., 2013, no. 10, pp. 200-210. (In Russian) 
Tyurin Anatoly Matveevich, Candidate of Geological and Mineralogical Sciences, Head of the Geophysics Laboratory; Associate Professor, Department of Geology, Geodesy and Cadastre

Volga-Urals Research and Design Institute for Oil and Gas

ul. Pushkinskaya, 20, Orenburg, 460000 Russia

Orenburg State University

pr. Pobedy, 13, Orenburg, 460018 Russia

E-mail: amturin1952@bk.ru

Kolomoets Alexandra Vyacheslavovna, Leading Engineer, Department of Geology and Geophysics; Senior Lecturer, Department of Geology, Geodesy and Cadastre

Volga-Urals Research and Design Institute for Oil and Gas ul. Pushkinskaya, 20, Orenburg, 460000 Russia

Orenburg State University

pr. Pobedy, 13, Orenburg, 460018 Russia

E-mail: kolomoyets56@mail.ru

Snachev Alexander Vladimirovich, Candidate of Geological and Mineralogical Sciences, Head of the Ore Deposits Laboratory

Institute of Geology, Ufa Federal Research Center, Russian Academy of Sciences ul. Karla Marksa, 16/2, Ufa, 450077 Russia

E-mail:SAVant@rambler.ru

Smoleva Irina Vladimirovna, Leading Chemical Engineer

Institute of Geology named after Academician N.P. Yushkin, Komi Science Center, Ural Branch, Russian Academy of Sciences

ul. Pervomayskaya, 54, Syktyvkar, 167982 Russia

E-mail: smolewa@geo.komisc.ru

Pankratyev Petr Vladimirovich, Doctor of Geological and Mineralogical Sciences, Professor, Department of Geology, Geodesy and Cadastre

Orenburg State University

pr. Pobedy, 13, Orenburg, 460018 Russia

E-mail: pankratev34@mail.ru

ОРИГИнА ЛьнАЯ С Т АТьЯ

УДК 551.1:552.522

doi: 10.26907/2542-064X.2021.3.466-476

\title{
Углеродистые формации каменноугольного возраста и перспективы нефтегазоносности Магнитогорского прогиба (Южный Урал)
}

\author{
А.М. Тюрин ${ }^{1,2}$, А.В. Коломоеи ${ }^{1,2}$, А.В. Сначёв ${ }^{3}$, И.В. Смолева ${ }^{4}$, П.В. Панкратьев ${ }^{2}$ \\ ${ }^{1}$ ООО «ВолгоУралНИПИгаз», г. Оренбург, 460000, Россия \\ ${ }^{2}$ Оренбургский государственный университет, г. Оренбург, 460018, Россия \\ ${ }^{3}$ Институт геологии Уфимского федерального исследовательского иентра РАН, \\ 2. Уфа, 450077, Россия \\ ${ }^{4}$ Институт геологии имени академика Н.П. Юшкина Коми научного иеетра \\ Уральского отделения РАН, г. Сыктывкар, 167982, Россия
}

\begin{abstract}
Аннотация
Перспективы нефтегазоносности Магнитогорского прогиба Южного Урала обоснованы по результатам геологической съемки и глубокого бурения. В Кизильской зоне по данным сейсмо-, грави- и магниторазведки выявлена крупная структура по карбонатам нижне-среднекаменноугольного возраста. По результатам бурения в них отмечены нефтегазопроявления. Дальнейшее обоснование перспектив нефтегазоносности региона выполнено по особенностям характеристик черных сланцев. Показано, что сланцы Кумакского рудного поля являются потенциально нефтематеринскими породами; депрессионными аналогами нефтегазоперспективных шельфовых
\end{abstract}


карбонатов нижне-среднекаменноугольного возраста. Рекомендовано продолжить их изучение в контексте дальнейшего обоснования перспектив нефтегазоносности Южного Урала. Главные научные задачи - локализация в пределах Магнитогорского прогиба и Восточно-Уральского поднятия фаций бассейна карбонатной седиментации и разработка его геолого-геофизической модели, оценка на ее основе перспектив нефтегазоносности региона и обоснование постановки региональных сейсморазведочных работ МОГТ.

Ключевые слова: углеродистые сланцы, органический углерод, изотопный состав углерода, бассейн седиментации, нефтегазоносность, Южный Урал, Магнитогорский прогиб, ВосточноУральское поднятие

Благодарности. Работа выполнена при финансовой поддержке корпоративного гранта АО «Оренбургнефть» (2020-2021 гг.) и в рамках госзадания по теме № 0246-2019-0078 (Институт геологии УФИЦ РАН, г. Уфа).

Поступила в редакцию 06.07.2021

Тюрин Анатолий Матвеевич, кандидат геолого-минералогических наук, заведующий лабораторией геофизики; доцент кафедры геологии, геодезии и кадастра

ООО «ВолгоУралНИПИгаз»

ул. Пушкинская, д. 20., г. Оренбург, 460000, Россия

Оренбургский государственный университет

пр. Победы, д. 13, г. Оренбург, 460018, Россия

E-mail: amturin1952@bk.ru

Коломоец Александра Вячеславовна, ведущий инженер отдела геологии и геофизики ООО; старший преподаватель кафедры геологии, геодезии и кадастра

ООО «ВолгоУралНИПИгаз»

ул. Пушкинская, д. 20., г. Оренбург, 460000, Россия

Оренбургский государственный университет пр. Победы, д. 13, г. Оренбург, 460018, Россия

E-mail: kolomoyets56@mail.ru

Сначёв Александр Владимирович, кандидат геолого-минералогических наук, заведующий лабораторией «Рудных месторождений»

Институт геологии Уфимского федерального исследовательского центра РАН ул. Карла Маркса, д. 16/2, г. Уфа, 450077, Россия

E-mail:SAVant@rambler.ru

Смолева Ирина Владимировна, ведущий инженер-химик

Институт геологии имени академика Н.П. Юшкина Коми научного центра Уральского отделения РАН

ул. Первомайская, д. 54, г. Сыктывкар, 167982, Россия

E-mail: smolewa@geo.komisc.ru

Панкратьев Пётр Владимирович, доктор геолого-минералогических наук, профессор кафедры геологии, геодезии и кадастра

Оренбургский государственный университет

пр. Победы, д. 13, г. Оренбург, 460018, Россия

E-mail: pankratev34@mail.ru

For citation: Tyurin A.M., Kolomoets A.V., Snachev A.V., Smoleva I.V., Pankrat'ev P.V. Carbonaceous deposits (carboniferous) and oil and gas potential prospects of the Magnitogorsk trough (South Urals). Uchenye Zapiski Kazanskogo Universiteta. Seriya Estestvennye Nauki, 2021, vol. 163, no. 3, pp. 466-476. doi: 10.26907/2542-064X.2021.3.466-476.

/ Для цитирования: Tyurin A.M., Kolomoets A.V., Snachev A.V., Smoleva I.V., Pankrat'ev P.V. Carbonaceous deposits (Carboniferous) and oil and gas potential prospects of the Magnitogorsk trough (South Urals, Russia) // Учен. зап. Казан. ун-та. Сер. Естеств. науки. - 2021. T. 163, кн. 3. - C. 466-476. - doi: 10.26907/2542-064X.2021.3.466-476. 